Національна академія Державної прикордонної служби України імені Богдана Хмельницького, Хмельницький

\title{
Інформаційна модель оперативно-розшукової діяльності оперативних підрозділів Державної прикордонної служби України
}

Резюме. У статті розроблено інформаційну модель оперативно-розшукової діяльності оперативних підрозділів Державної прикордонної служби України. Коротко надано опис та проаналізовано структуру інформаційної моделі. Запропоновано окремі критерії, яким має відповідати інформаційна модель.

Ключові слова: інформація, модель, оперативний підрозділ, оперативно-розшукова діяльність, інформаційний потік, інформаційно-аналітична взаємодія, об'єкт.

Постановка проблеми. Кожна країна світу в сучасних умовах розвитку людства надає пріоритет надійному захисту державного суверенітету, територіальної цілісності, демократичного конституційного ладу та інших національних інтересів від реальних і потенційних загроз. Для цього в Україні правоохоронні органи та служби виконують широкий спектр функцій, які узагальнено в IV розділі Закону України "Про національну безпеку України” [1]. Так, однією із функцій Державної прикордонної служби (ДПС) України у сфері забезпечення безпеки кордону є ведення оперативно-розшукової діяльності (ОРД) [2]. Така діяльність в ДПС України здійснюється спеціально уповноваженими законодавством України оперативно-розшуковими підрозділами (далі- оперативні підрозділи) [3].

Завданням ОРД $є$ пошук i фіксація фактичних даних про протиправні діяння окремих осіб і груп, відповідальність за які передбачена Кримінальним кодексом України, розвідувально-підривну діяльність спеціальних служб іноземних держав та організацій для припинення правопорушень i в інтересах кримінального судочинства, а також отримання інформації в інтересах безпеки громадян, суспільства i держави [3]. Отже, процес отримання інформації $є$ первинним, а значить, має вплив на результати діяльності оперативного підрозділу.

На основі аналізу підсумків оперативнослужбової діяльності оперативних підрозділів ДПС України встановлено, що в умовах постійного впливу низки факторів i загроз прикордонній безпеці висока ефективність виконання завдань досягається завдяки постійному вдосконаленню всіх іiі форм, зокрема інформаційно-аналітичної діяльності. Для поліпшення інформаційно-аналітичної діяльності оперативних підрозділів ДПС України здійснюється: розширення повноважень оперативних підрозділів щодо отримання інформації, зокрема 3 використанням спеціальних технічних засобів; удосконалення прийомів i способів збирання (добування) та обробки інформації; формування інтегрованих, захищених інформаційно-пошукових баз даних; створення дієвого механізму оперативного співробітництва з правоохоронними органами на національному та міжнародному рівні, зокрема у сфері обміну інформацією, проведенні спільних оперативних заходів тощо [4]. Однак за результатами виконання зазначених заходів виявлено невідповідність існуючого в оперативних підрозділах ДПС України стану щодо обміну інформацією потребам у іiі вчасному отриманні та реалізації. Одним із способів усунення зазначеного недоліку $є$ побудова такої інформаційної моделі, яка б розкрила існуючий в оперативних підрозділах ДПС України потенціал для поліпшення інформаційно-аналітичної взаємодії та координації діяльності під час ОРД.

Аналіз останніх досліджень i публікацій. Дослідження інформаційноаналітичної та оперативно-розшукової діяльності органів і підрозділів ДПС України здійснювалось низкою вчених в [5-7] та інших працях. Так, у [5] розроблено моделі та методи інформаційних технологій інтелектуалізації підтримки прийняття рішень у діяльності ДПС України. У [6] запропоновано шляхи вдосконалення інформаційного забезпечення ОРД через узгодження підходів до збирання, оцінки і документування інформації; організацію системного обміну інформацією; застосування новітніх технологій у сфері оброблення інформації, іiі зберігання та передачі. Також досліджено методологію інформаційноаналітичного забезпечення ДПС України в контексті виконання завдань національної безпеки в прикордонній сфері та розроблено низку моделей i методик для оцінювання ефективності зазначеної діяльності. Іншим науковцем у [7] основна увага приділялась дослідженню актуальних питань взаємодії оперативних підрозділів ДПС України 3 
підрозділами Міністерства оборони України для формування раціонального варіанта комплексу сил і засобів розвідки.

На основі вивчення змісту наукових праць зазначених та інших вчених встановлено, що поза увагою авторів залишилось питання саме щодо сучасного розуміння інформаційної моделі ОРД оперативних підрозділів ДПС України. 3 огляду на це необхідність побудови чіткої інформаційної моделі ОРД оперативних підрозділів ДПС України і визначає актуальність теми дослідження.

Мета статті полягає у розробленні інформаційної моделі оперативно-розшукової діяльності оперативних підрозділів ДПС України.

Виклад основного матеріалу. Відповідно до загальноприйнятого визначення інформаційною моделлю $€$ сукупність інформації, яка характеризує властивості та стан об’єкта, процесу чи явища, а також їхню взаємодію із зовнішнім середовищем [8]. Така модель описує інформаційні процеси або містить інформацію про властивості й стан об'єктів, процесів, явищ. Отже, у межах нашого дослідження інформаційною моделлю (моделлю) ОРД оперативних підрозділів ДПС України (рис. 1) є сукупність інформації, що описує структуру та напрями інформаційних потоків інформаційно-аналітичної взаємодії, які системно циркулюють в інформаційному просторі для забезпечення виконання завдань, визначених законодавством України.

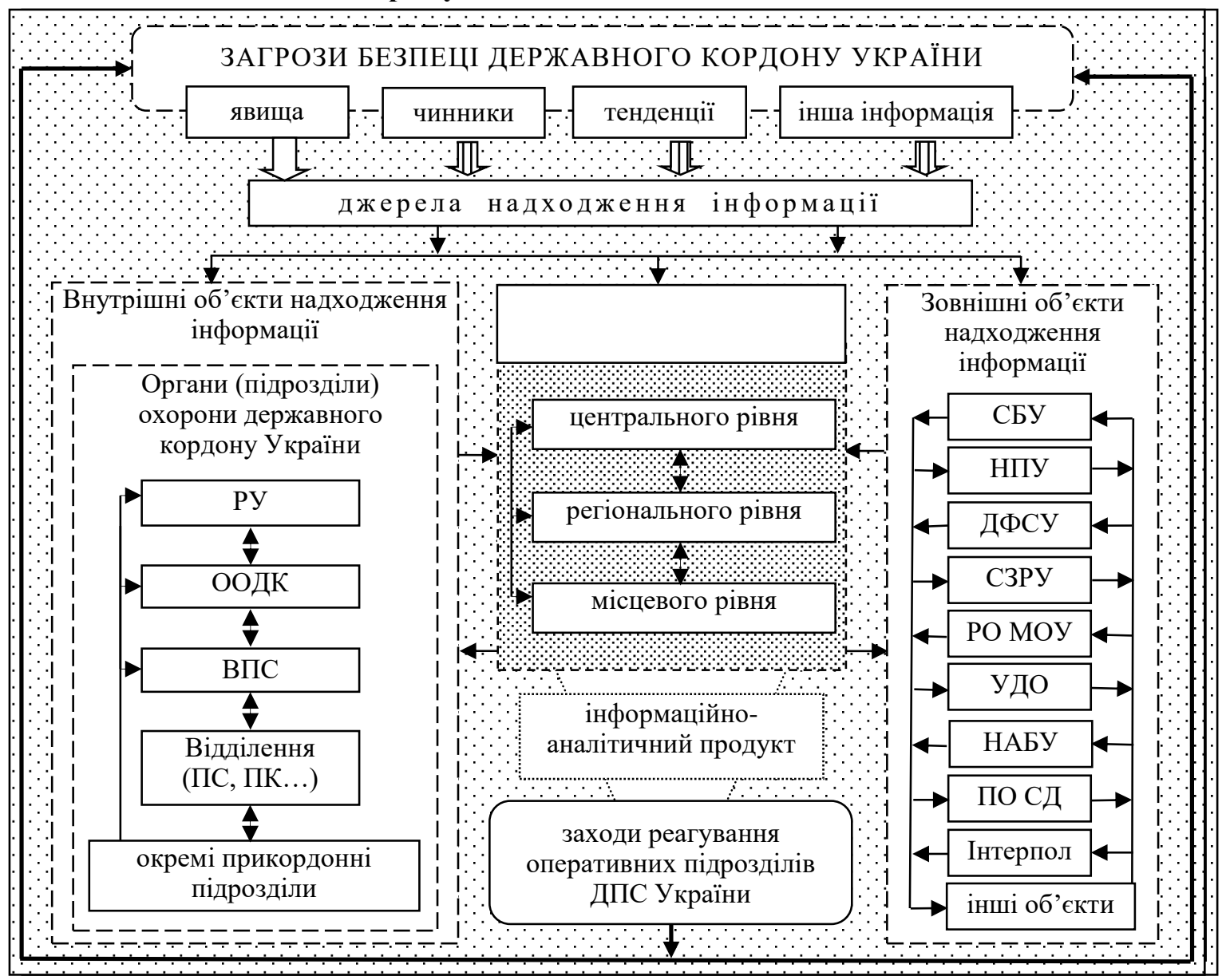

Рис. 1. Інформаційна модель оперативно-розшукової діяльності оперативних підрозділів Державної прикордонної служби України

СБУ - Служба безпеки України;

НПУ - Національна поліція України;

ДФСУ - Державна фіскальна служба України;

СЗРУ - Служби зовнішньої розвідки України;

УДО - Управління державної охорони;

РО МОУ - Розвідувальний орган Міністерства оборони

України;

НАБУ - Національне антикорупційне бюро України;

На основі аналізу змісту джерел $[8,9]$ у моделі ОРД оперативних підрозділів ДПС України застосовується низка понять. Так,
ПО СД - правоохоронні органи суміжних держав, спільнот;

ООДК - орган охорони державного кордону;

РУ - регіональне управління;

ВПС - відділ прикордонної служби;

ПС - прикордонна служба;

ПК - прикордонний контроль;

внутрішній інформаційний простір; зовнішній інформаційний простір

інформаційним простором $\epsilon$ середовище, у якому відбуваються процеси щодо збирання, одержання, зберігання, використання, 
поширення, охорони та захисту інформації, створення інформаційних ресурсів і продуктів, а також інформаційно-аналітична взаємодія для задоволення потреб відповідно до чинного законодавства. Інформаційним потоком $\epsilon$ цілеспрямоване проходження інформації різних видів за заданими напрямами. І Інформаційно-аналітична взаємодія -це порядок взаємного обміну інформацією між іï споживачами для повнішого і якіснішого виконання покладених на них завдань. Споживачами інформації $\epsilon$ визначена встановленим порядком посадова особа, підрозділ, частина, установа, орган державного або військового управління, які використовують інформацію для виконання поставлених перед ними завдань. На рис. 1 споживачами інформації $\epsilon$ оперативні підрозділи ДПС України, внутрішні та зовнішні об' єкти надходження інформації.

Незважаючи на те, що із внесенням змін в законодавство України 3 листопада 2019 року оперативні підрозділи ДПС України ввійшли до складу органів охорони кордону та відділів прикордонної служби, на рис. 1 їх структура відокремлена. Це зв'язано зі специфікою ОРД та особливостями інформаційно-аналітичної діяльності оперативних підрозділів, продуктом якої $\epsilon$ оперативно-розшукова інформація, аналітичні звіти кримінального аналізу за оперативнорозшуковими справами та інше, що має гриф обмеження доступу та допуску до інформації. Крім того, оперативні підрозділи ДПС України в процесі інформаційно-аналітичної взаємодії між собою формують внутрішній інформаційний простір, який надає можливість здійснювати обмін та обробку інформації із використанням інформаційнотелекомунікаційної системи “Гарт-10”. Ця система призначена для автоматизації діяльності посадових осіб оперативних підрозділів щодо збору, передачі та збереження інформації про обстановку на державному кордоні та результатів ОРД; аналітичної обробки отриманої інформації; формування статистичної інформації, звітів, довідок та інших продуктів, обміну ними в рамках інформаційно-аналітичної взаємодії. Така взаємодія передбачає циркуляцію інформаційних потоків на різних рівнях ОРД ДПС України. Так, до центрального рівня належать Департамент оперативної діяльності Адміністрації ДПС України, Головний центр оперативно-технічних заходів. На регіональному рівні свою діяльність здійснюють управління організації ОРД, регіональні центри оперативно-технічних заходів. Місцевий рівень - головні та прикордонні оперативно-розшукові відділи.

Оперативні підрозділи ДПС України в процесі ОРД поєднані різнорідними потоками інформації: від джерел інформації до окремого оперативного підрозділу ДПС України; усередині окремого оперативного підрозділу ДПС України; між оперативними підрозділами ДПС України у горизонтальних і вертикальних напрямах; між оперативними підрозділами та іншими структурними підрозділами ДПС України; між оперативними підрозділами ДПС України та оперативними підрозділами інших правоохоронних органів України; між оперативними підрозділами ДПС України та правоохоронними органами іноземних держав i міжнародних організацій, спільнот.

У представленій моделі на вхід надходить гетерогенна інформація про обстановку на державному кордоні України. Тут особлива увага приділяється інформації про загрози: явища, тенденції і чинники, що реально або потенційно унеможливлюють чи ускладнюють реалізацію державної політики у сфері безпеки державного кордону $[1,4]$. Зміст таких загроз в умовах сьогодення визначено у Стратегії національної безпеки України, Стратегії воєнної безпеки України, Стратегії кібербезпеки України, інших документах 3 питань національної безпеки i оборони, які схвалюються Радою національної безпеки i оборони України i затверджуються указами Президента України. Водночас, важливою $\epsilon$ інформація про загрози в інформаційній сфері, а саме: здійснення спеціальних інформаційних операцій, провокування екстремістських виявів, загострення i дестабілізацію суспільнополітичної та соціально-економічної ситуації, розпалювання міжетнічних і міжконфесійних конфліктів в Україні; поширення закликів до радикальних дій, пропаганда ізоляціоністських та автономістських концепцій співіснування регіонів в Україні та інше [10].

Отримана інформація проходить первинну обробку і перетворюється у форму, необхідну для подальшого обліку, систематизації, аналізу, накопичення, прогнозування та розроблення інформаційноаналітичних документів. До таких документів належать матеріальні носії інформації, які містять всебічно проаналізовані та узагальнені дані щодо виконання завдань та відповідний прогноз розвитку обстановки (подій, явищ), викладені за визначений термін часу, в обсязі та формі, що вимагається [9]. Прикладом інформаційно-аналітичних документів $€$ 
аналітичний звіт, який містить узагальнені відомості 3 певного питання або предметної області дослідження, прогнози та пропозиції щодо подальших дій.

У випадках, якщо в оперативних підрозділах ДПС України наявних даних недостатньо для виконання завдань ОРД і для розв'язання питань інформаційно-аналітичної взаємодії, здійснюється добір і обмін інформацією із зовнішнього інформаційного простору через інформаційні потоки внутрішніх і зовнішніх об’єктів ії надходження.

Інформаційні потоки внутрішнього i зовнішнього інформаційного простору розробленої моделі мають певні властивості, які характеризуються за змістом, методами отримання, формою передачі та інтенсивності обміну інформацією між оперативними підрозділами ДПС України і об'єктами іï надходження тощо. Тут параметрами та показниками кількісно-якісної характеристики інформаційних потоків $\epsilon$ : зміст інформації в інформаційному потоці (за показниками, наприклад, достовірність, повнота); обсяг інформації в інформаційному потоці; час проходження інформації в інформаційних потоках до оперативних підрозділів ДПС України; швидкість проходження інформації в інформаційному потоці; інтенсивність обміну інформацією тощо.

Для прикладу розглянемо зміст інформації за показником “достовірності”.

Усю інформацію, яка надходить до оперативних підрозділів ДПС України від різних джерел, прийнято оцінювати за методом “4x4” [12]. Цей метод дає змогу визначити ступінь відповідності відомостей про події, явища та об'єкти фактичному стану справ із застосуванням значень: "1" - для інформації, точність якої не підлягає сумніву; “2”- для інформації, яка відома особисто джерелу, але не відома особисто співробітнику, який іiі отримав від цього джерела; “3” - для інформації, яка не відома особисто джерелу, однак підтверджується іншою, раніше отриманою інформацією; “4”- для інформації, яка не відома особисто джерелу i яку неможливо підтвердити.

Водночас, оцінюється і джерело інформації, якому привласнюються значення: “А” - джерело, щодо якого відсутні підозри в підробці або спотворенні інформації (наприклад, оперуповноважений оперативного підрозділу); “В”- джерело, яке може мати помилки, допущені під час внесення даних електронна або матеріальна база даних (наприклад, база даних “iBase”); “C” - джерело, інформацію від якого необхідно додатково перевіряти (наприклад, лісник прикордонного селища); "D” - джерело нове, раніше не відоме, $\mathrm{i}$ достовірність якого в певний час не може бути визначена.

Кожна протиправна подія, яка відбувається або може відбутися на державному кордоні, має притаманну їй характеристику за певним описом сукупної інформації. Такий опис охоплює відповіді на основні питання: що?, де?, коли?, чому?, у який спосіб?, за допомогою чого?, хто? [12]. Тут показником достовірності інформації є властивість реально описати подію 3 певною точністю.

Якщо використовувати метод “4x4”, то достовірність інформації про подію вимірюється ймовірністю того, що значення параметра, який відображає отриману інформацією, відповідає значенню цього параметра в межах точності від 0 до 1. Так, наприклад, достовірність інформації зі значенням “4” має точність у межах від 0 до 0,25. Достовірність високої точності (від 0,75 до 1) має значення "1" - як приклад, інформація отримана від оперуповноваженого оперативного підрозділу.

Кожна інформація про події, яка надійшла в оперативний підрозділ ДПС України, вивчається насамперед за джерелом походження та уточнюється за фактами, ознаками, які складають їі основу. Така інформація (первинна інформація) обов'язково перевіряється через інші джерела та аналізується на відповідність раніше отриманим даним. Водночас, таж сама інформація про подію може подаватись у різному контексті та сприйматися по-різному.

Так, достовірність інформації збільшується, якщо вона отримана від першоджерела, адекватно описує реальну подію та правильно розуміється особою, яка цю інформацію отримала від першоджерела.

На виході моделі формується така інформація, яка використовується для прийняття управлінських рішень на проведення заходів ОРД відповідно до повноважень оперативних підрозділів ДПС України. Від ефективності реалізації цих заходів залежить успіх протидії загрозам безпеки державного кордону та його охорони загалом. Отже критеріями, яким має відповідати інформаційна модель ОРД оперативних підрозділів, є наявність дієвого технічного обладнання для циркуляції інформаційних потоків із дотриманням конфіденційності та режиму доступу, стабільність ефективного обміну інформацією між оперативними підрозділами та об'єктами іiі надходження, здатність моделі виконувати завдання для забезпечення високого 
рівня результативності ОРД тощо.

Висновки. Таким чином, розроблено інформаційну модель, яка за сукупніс

тю інформації описує структуру та напрями інформаційних потоків інформаційно-аналітичної взаємодії, які системно циркулюють в інформаційному просторі. Виконання в практичній діяльності посадовими особами оперативних підрозділів ДПС України розрахунків за запропонованими показниками та критеріями дасть змогу проаналізувати та поліпшити стан обміну інформацією, необхідною для ОРД.

У подальших дослідженнях доцільно розробити низку моделей і методів щодо роботи 3 інформацією в процесі ОРД оперативних підрозділів ДПС України.

\section{СПИСОК ВИКОРИСТАНОЇ ЛІТЕРАТУРИ}

1. Про національну безпеку України : Закон України від 21.06.2018 № 2469-VIII. Відомості Верховної Ради України. 2018, № 31, ст. 241.

2. Про Державну прикордонну службу України : Закон України від 03.04.2003 р. № 661-IV. Відомості Верховної Ради України. 2003. № 27. Ст. 208.

3. Про оперативно-розшукову діяльність : Закон України від 18.02 .1992 p. № 2135-XII. Дата оновлення: 12.11.2019. URL: http://zakonl.rada.gov.ua/laws/ show/2135-12/page (дата звернення: 12.09.2019).

4. Про схвалення Стратегії інтегрованого управління кордонами на період до 2025 року : Розпорядження Кабінету Міністрів України від 24.07.2019 р. № 687-р. URL: http://zakon.rada.gov.ua/laws/main/index (дата звернення: 21.09.2019).

5. Андрощук О.С. Інформаційні технології інтелектуалізації підтримки прийняття рішень у діяльності Державної прикордонної служби України : монографія. Хмельницький : НАДПСУ, 2011. 222 с.

6. Білецький В. О. Інформаційне забезпечення оперативно-розшукової діяльності у прикордонній сфері. Публічне управління: теорія та практика, 2013. C. $176-180$.

URL: http://nbuv.gov.ua/UJRN/Pubupr_2013_2_31.

7. Цигикал П. О. Актуальні питання взаємодії Міністерства оборони України та Державної прикордонної служби України для вирішення завдання 3 визначення раціонального варіанту комплексу сил і засобів розвідки : зб. наук. пр. / гол. ред. Б. М. Олексієнко. Хмельницький : НАДПСУ, 2017. № 27. С. 3-12.

8. Яременко В. Новий тлумачний словник української мови : тлумачний словник в 3 т., 2 вид., виправл. Київ : A.C.K, 1998. T. 2. 534 c.

9. ВСТ 01.101.004-2009 (01). Військовий стандарт. Терміни та визначення. Вид. офіц. Київ : Міністерство оборони України, 2009. 24 с.

10. Про рішення Ради національної безпеки і оборони України від 29 грудня 2016 року "Про Доктрину інформаційної безпеки України” : Указ Президента України від 25.02.2017 №47/2017. URL: https://zakon.rada.gov.ua/laws/show (дата звернення: 23.09.2019)

11. Про затвердження інструкції про порядок оцінки інформації за методом 4x4 : наказ Адміністрації Державної прикордонної служби України від 19.01.2008 p. № 44. 2008. 8 c.

12. Киреєва О. С., Фаріон О.Б. Короткий тлумачний словник керівника підрозділу кримінального аналізу : словник. Хмельницький : НАДПСУ, 2016. 68 с.

\section{Стаття надійшла до редакційної колегії 17.12.2019}

\section{Information model of operational and search activity the of operational units of the state border guard} service of Ukraine

\section{Annotation}

In the scientific article the definition and information model of the operational-search activity of the operational units of the State Border Guard Service of Ukraine are defined and developed. It is noted that such a model is a set of information describing the structure and directions of information flows of information-analytical interaction, which systematically circulate in the information space to ensure the fulfillment of tasks defined by the laws of Ukraine. The information model and its structure is described and analyzed. The levels of the State Border Guard's Service of Ukraine operational and search units and the internal and external objects of information are presented. The procedure of forming the internal and external information space of the information model is briefly explained.

It is noted that in the process of the activity the operational-search units of the State Border Guard Service of Ukraine are united by different flows of information, the list of which is provided. In addition, it is noted that the information flows of the internal and external information space of the developed model have certain properties, which are characterized by the content, methods of receiving, the form of sending and the intensity of information exchange between the operational and search units and the objects of its receipt. Parameters and indicators of quantitative and qualitative characteristics of information flows are determined. An example of estimating the content of information in the information flow by the indicator of reliability using the method "4x4" and an approach to its improvement is given. The criteria for the information model of the operative-search activity of the operational-search units of the State Border Guard Service of Ukraine should meet is suggested. It is stated that the creation of an information model is a necessary stage for further research of the information-analytical activity of the operationalsearch units of the State Border Guard Service of Ukraine. object.

Keywords: information, model, operational unit, search activity, information flow, information-analytic interaction, 